\title{
Integrating Soft Skills into Courses in Malaysian Public Universities
}

\section{(Undergraduates' Perception)}

\author{
Maya Khemlani David \\ Faculty of Language and Linguistics, University of Malaya, Malaysia \\ Neda Saeipoor \\ Faculty of Language and Linguistics, University of Malaya, Malaysia
}

\begin{abstract}
Malaysian employers demand a high proficiency in soft skills. They are looking beyond academic results when interviewing new staff, hence undergraduates acquiring soft skills is an important issue from different perspectives: the employers, the education system and the students themselves. Despite this emphasis, potential employees, according to employers; lack soft skills. Considering the importance of this issue, this paper's objective is to comprehend and highlight the perception of undergraduates of the soft skills programs in five research universities in Malaysia. The information presented in this paper is obtained from a survey conducted by distributing 600 questionnaires to undergraduates in Malaysia's five research universities to determine their understanding of soft skills and how these skills are taught and evaluated in these universities. The initial findings show that there is a strong awareness of the importance of soft skills among undergraduates but the students are not clear about the methods of teaching and evaluating these skills in different courses in different universities. The results illustrate a need for universities in general to develop strategies to enhance soft skills teaching and learning and make undergraduates aware of how these skills are evaluated. The results also suggest that integrating soft skills into university courses does not follow a standard procedure and each university may value and emphasis a different skill. It appears therefore that if universities collaborate their knowledge and experience, they may be able to offer a more practical and beneficial soft skill-training program for undergraduates.
\end{abstract}

Key words: $\quad$ Tertiary Education, Soft Skills, Employability, Educational Policy

\section{Introduction}

This research study was conducted to provide insight on the effectiveness of soft skills integration in university courses on undergraduates' employability in Malaysia. The study aimed to investigate the issue of lack of soft skills in potential employees and its effect on the increasing rates of unemployment among Malaysian public university graduates from the perspective of the university students.

The term 'soft skills' has been defined in different ways and includes various skills based on the context. Soft skills are a set of individual qualities, attitudes and social knowledge that are expected from a good employee. Moss and Tilly (1996) suggest that soft skills are abilities and characters that relate to personality and attitude and is different from technical knowledge.

While there is no specific list naming 'soft skills' (also known as employability skills, transferable skills, job readiness skills), the Malaysian Ministry of Higher Education (MOHE) defines soft skills as integrating aspects of a wide range of skills including non-academic skills such as communication, leadership, lifelong learning and teamwork/ these skills specifically includes the following seven skills as 'soft' i.e. Communication skills, Critical thinking and problem solving, Entrepreneurship, Ethics, Leadership, Lifelong learning and information management and Team work (Roselina Shakir 2007). Since we are concerned with the Malaysian academic context, this definition and its seven components are considered as the operational definition for the term 'soft skills' in this paper.

To integrate these skills in university programs for undergraduates, MOHE has suggested the following methods to develop and enhance these soft skills for the undergraduate programs at universities. These methods include: embedding soft skills in the existing syllabus, offering stand-alone subjects, campus life activities, offering support programs, 


\section{Yinternational Research Journal}

p-ISSN 2202-2821 e-ISSN 1839-6518 (Australian ISSN Agency)

formal and informal activities at faculty levels and industrial training.

\section{A. Soft skills and employment in Malaysia}

Malaysia like many other countries, is confronting a new economic developmental challenge due to globalization. The world's economies are increasingly interrelated through financial investment, human resource investment, competition and cooperation. In this new work culture knowledge of soft skills is crucial to organization performance. As a consequence, globalization has caused a noticeable effect on the demand for specific soft skills in the workforce in Malaysia (Khairol Mohd Salleh, et.al. 2010).

With Malaysia rapidly moving towards new fields to reach its economic goals, the workplace culture is shifting rapidly. This shift, carried out by the government's many transformation programs necessitates the potential work force to have the soft skills needed to adapt to new requirements (Fernandez, 2013). Under the new discipline it is vital for employees to exhibit a soft skills competency along with hard skills to get jobs (McLarty, 2000).

Higher education institutes have a responsibility to provide the new workforce with these skills. Consequently, there has been a growing demand from Malaysian employers that universities and colleges should produce graduates with suitable 'soft skills'. Employers demand comprehensive graduates who possess soft skills in addition to technical skills, and preferably, work experience. One of the reasons for unemployment is lack of soft skills (Act of Workers with 'Soft Skills' Demands a Shift in Teaching, 2009).

According to the final report of Skills Development: Attitudes \& Perceptions in March 2008,

Malaysia shows a higher lack in soft skills than Australia, Denmark, the UK and Germany. The report emphasizes that the employers and practitioners alike are aware that sometimes, training in a technical area is not enough to make a person employable. The soft 'employability' skills of an existing or potential employee are as essential as the qualification they have gained. Soft skills are seen as vitally important for industry today.

The incompatibility in what students learn in universities and what they need in the workplace is an ongoing concern. Employers all over the world and in Malaysia always are concerned about finding graduates with the necessary skills (Dunne \& Rawlins, 2000; Lee, 2003, Bakar \& Hanafi, 2007; Shah, 2008; Sidhu, 2011).

Furthermore, employers and professional bodies worldwide are in consensus that higher education institutions should
Vol. 08 No. 012018

82800801201802

adapt and change at an even greater pace than in the past in order for them to develop a highly skilled and ready workforce to face the challenges of the global competition (Ministry of Higher Education Malaysia, 2006).

To be competitive, Malaysia should have an education system that is able to produce ready to work graduates. Students' soft skills need to be developed to get them ready for the workplace. The significance of this problem has led many Malaysian researchers to conduct studies in order to understand the root of the problem and provide practical solutions. They have looked at the problem from different perspectives. Most of these studies, some of which are briefly introduced below, have focused on the employers expressing their needs and demands. On the other hand, some have looked at the problem from the perspective of universities and academics. There are a few studies, which focus on Malaysian university students' needs or understanding of the soft skills. These studies are mostly restricted to one university or a specific field. The current research fills this gap by encompassing a large number of undergraduates in public universities throughout Malaysia and includes undergraduates from various faculties and disciplines in five leading Malaysian universities.

A few of the studies on soft skills and employability from different perspectives are presented here to give the reader an idea about the nature of the problem and the research conducted in Malaysia.

Yasmin Mohd Adnan, et al. (2012) argue that the modern employment market in Malaysia needs fresh graduates to be more competent, which necessitates acquiring soft skills. These researchers emphasize the soft skills identified by the Malaysian Ministry of Higher Education (MOHE) to enhance graduates' employability. They focus on the significance of those soft skills in the real estate field and suggest emphasis on curriculum development.

To learn about the needs of employers and evaluate the fresh workforce, Ramah Ismail, Ishak Yussof and Lai Wei Sieng (2011), applied the job matching theory to study the perception of 749 employers in Lembah Klang (Selangor) services sector on graduates' performance through a questionnaire. Their participants included employers, human resource managers and organization department heads. In general, their results show that the employers believe that the graduates' performance regarding soft skills is satisfactory but not the best. They conclude that universities and colleges still need to work hard to improve the soft skills of their graduates in the modern job market where quality rather than quantity is needed more. 


\section{Yinternational Research Journa}

p-ISSN 2202-2821 e-ISSN 1839-6518 (Australian ISSN Agency)

In another study with regard to the Issue of Soft Skills and Different Courses in Malaysian Universities, Ramakrishnan and Yasin (2011) applying quantitative (questionnaire) and qualitative (short interviews) methods, aimed to determine the causes of unemployment problem among Malaysian information and communication technology (ICT) graduates and the need for changes in the curriculum. They studied 296 current undergraduate students and 248 graduates from public universities in Malaysia. They found that mismatch of qualifications with needs of employers, lack of demand and supply information of the labour market, lack of soft skills, lack of students' exposure to the real job market, lack of proper career guidance and information, unchallenging course syllabus, lack of industrial training/internship courses, students' attitude, and teacher-centred classes could be the cause of unemployment of graduates. They suggested that higher education institutes need to reengineer their curriculum in order to keep them updated in-line with the needs of employers.

In another survey on 30 employers in engineering industries in the Klang Valley area, Azami Zaharim, et al (2009) investigated the satisfactory perception of the level of skills of engineering graduates in the work place. They found that there is a gap between the skills possessed by potential graduates and the skills deemed important by employers. The important skills required are the ability to work as an individual as well as in a team, communication and problem solving, skills in lifelong learning and understanding professional, social and ethical responsibilities.

Along the same line, Hazmilah Hasan (2008) conducted a Generic Transfer Questionnaire survey on 269 final year engineering undergraduates of two Malaysian public and two private universities to explore whether the lack of soft skills abilities can be a cause of unemployment amongst engineering graduates in Malaysia. The results suggested the inclusion of grooming classes, more university and industry collaboration, a specialized engineering programme, extending industrial training, replacing exam-oriented systems with more practical skills and a chance to explore society for personal development.

The gap between employers' requirements and business graduates' abilities was studied by Shirley Ken Tzu Ting and Cheah Yeh Ying (2012) who tried to determine the perception of employers on important competencies in the Malaysian banking industry. They attempted to identify the actual performance of Malaysian business graduates by comparing their general skills and the universities they had attended. The study revealed that with some limitations the employers' perceptions of local graduates in this field is satisfactory even
Vol. 08 No. 012018

82800801201802

though the graduates were still unable to achieve an excellent grade in terms of the "soft skills" required.

Another study on soft skills is the study by Riam Chau Mai (2012) on employers' and students' perceptions of soft skills competencies. The participants of this study were employers and students from the northern region of Peninsular MalayaKedah, Perlis and Penang. He concludes that the employers are satisfied with students' competency in time management skills while teamwork, communication, and interpersonal skills are where improvements are needed most and more emphasis should be placed on skills like decision making, problem solving and leadership due to an increasing demand for such skills by employers.

Another interesting research by Hairuzila Idrus (2009) was conducted through questionnaire survey on the challenges confronted by 125 lecturers at a private university in Malaysia trying to integrate soft skills in the syllabus of their technical courses. The results indicated three main challenges the teachers faced i.e. a) students' behaviour in the classroom, b) inadequate time to complete the syllabus and c) large numbers of students in a classroom.

Subsequently, Hairuzila Idrus, Hazadiah Mohd Dahan and Normah Abdullah (2010) studied the teaching approaches employed by 90 lecturers in four engineering courses at a private university in which the emphasis was on critical thinking and problem-solving skills. Idrus, Dahan and Abdullah (2010) also attempted to determine lecturers' and students' views on the integration of soft skills in the curriculum. It was found that both the lecturers and the final year students considered critical thinking and problem-solving skills as the most important skill.

Although some research has been done on soft skills issue, the inadequacy of the university system in preparing undergraduates to fulfil the requirements of the employers with regard to these skills is obvious and can be traced in increasing undergraduate unemployment rates. This study tends to look at this problem from another perspective; from that of the undergraduates.

\section{II.Objectives}

The aim of the present study is to find out the status of soft skills integration in the academic curriculum from the perspective of undergraduates. The following research questions are devised to fulfill this objective:

- How do undergraduates from these public universities perceive soft skills?

- What is the undergraduates' perception on soft skills integrated in academic courses? 


\section{Yinternational Research Journal}

p-ISSN 2202-2821 e-ISSN 1839-6518 (Australian ISSN Agency)

- Are the undergraduates aware of how the integrated soft skills are evaluated?

\section{Methodology}

To attain the objectives of the study and answer the research questions we needed to collect data from a sample of Malaysian undergraduates as the population. This population is conducted of all students studying in Malaysian public universities. There are 20 public universities located in Peninsular Malaysia and east Malaysia, five of which are Research Universities with relatively high ranks in international rankings and higher numbers of undergraduate students. The sample for the study included 600 undergraduate students from these universities in different parts of Malaysia.

A survey design was used to collect data from the sample. We needed to devise a valid questionnaire since there was no instrument found in the literature to be suitable for our sample and include all the aspects of soft skills which were recognized as important by Malaysian universities.

\section{A. Questionnaire}

Questionnaires offer an objective means of collecting information about people's knowledge, beliefs, attitudes, and behavior. They are the most frequently used data collection method in educational and evaluation research.

The researchers made use of compromising quantitative and qualitative methods to increase the validity of the research in general and the research instruments in particular. A focus group interview was conducted with some volunteer undergraduate students. This paper tends to describe how the information from the focus group was used to develop a valid and reliable questionnaire.

To devise the questionnaire a literature review was conducted, and the basic structure of the questionnaire was built. To devise the items and ensure the content validity we conducted a focus group interview based on the basic structure.

The interview was transcribed and qualitatively analyzed. The emerged themes and categories combined with the information gathered from the literature review were then used to devise the questionnaire. 600 questionnaires from undergraduates in Malaysian public universities were collected.

To begin we chose a panel of experts including academic members of University of Malaya as the oldest university established in Malaysia. The Each member independently developed a set of questions to elicit the valid data from the sample. These themes were developed based on the literature review and their local and international knowledge about the situation. After several revisions we found out that the
Vol. 08 No. 012018

82800801201802

questions could roughly be classified into three major domains of

1) perceptions on soft skills,

2) perceptions on integration of soft skills into university courses and

3) students' perceptions with regard to each skill and its importance for employability after graduation.

Next, we recruited a sample of undergraduates, representing our larger sample of undergraduate students in Malaysian public universities. This group conducted of 10 undergraduate students from different faculties in university Malaya; was invited to a focus group interview. This was a semi-structured interview with open-ended questions devised based on Kvale and Brinkman (2008) and questions were based on the three domains accepted by the panel of experts. Using the list of trigger questions, we encouraged the participants to share their ideas and experiences about soft skills and their integration into their academic programs. The transcription was then analyzed using content-analysis methods. Group members' responses fit the domains in general, but there were some ambiguous areas such as the nature and number of the soft skills needed to be studied. The focus group data was used to determine 6sub-domains for the soft skills including communicative skills, critical thinking and problem solving, lifelong learning and information management, Entrepreneurship, teamwork and leadership and ethics.

The focus-group data was used to develop a questionnaire based on the three main domains. We then sent the questionnaire to a convenience sample of 20 undergraduate students to assess its comprehensibility. This led to some further modifications including language simplification for some questions. Also, the items were reduced from 132 to 83 items to make the questionnaire shorter and more convenient for the participants.

The final version of the questionnaire with 83 items including items to elicit necessary demographic information was then used in a pilot test to assess its reliability. 17 completed questionnaires were returned and Cronbach's Alpha (Alan \& Yen 2002; Blend \& Altman 1997; Cronbach \& Shavelson 2004) was used to determine the internal consistency of the items in the questionnaire to gauge its reliability. The results of the statistic procedures are presented in tables 1 to 4 .

Table 1: Case Processing Summary

\begin{tabular}{|l|l|l|}
\hline & $\mathbf{N}$ & \% \\
\hline Cases Valid & 17 & 100.0 \\
Exchange^ $^{\wedge}$ & 0 & 0 \\
Total & 17 & 100.0 \\
\hline
\end{tabular}

$\wedge$ - Listwise deletion based on all variables $n$ the procedure. 
Table 2: Reliability Statistics

\begin{tabular}{|c|c|c|}
\hline $\begin{array}{c}\text { Cronbach's } \\
\text { Alpha }\end{array}$ & $\begin{array}{c}\text { Cronbach's Alpha } \\
\text { Based on } \\
\text { Standardized } \\
\text { Items }\end{array}$ & N of Items \\
\hline .735 & .877 & 82 \\
\hline
\end{tabular}

Table 3: Summary Item Statistics

\begin{tabular}{|l|l|l|l|l|l|}
\hline & Mean & Minimum & Maximum & Range & $\begin{array}{l}\text { Maximum/ } \\
\text { Minimum }\end{array}$ \\
\hline Item Means & 2.267 & 1.059 & 4.235 & 3.176 & 4.000 \\
Item Variances & 1.381 & .059 & 57.846 & 57.787 & 983.375 \\
$\begin{array}{l}\text { Inter-Item } \\
\text { Covariances }\end{array}$ & .045 & -3.574 & 2.125 & 5.699 & -.595 \\
\hline
\end{tabular}

Table 4: Summary Item Statistics

\begin{tabular}{|l|l|l|}
\hline & Variance & N of Items \\
\hline Item Means & .519 & 82 \\
Item Variances & 39.979 & 82 \\
Inter-Item & .096 & 82 \\
Covariances & & \\
\hline
\end{tabular}

The revised validated questionnaire was used to collect the data for this study. The questionnaire was distributed to sample of 600 undergraduate students from research universities in Malaysia. These universities were selected because of their higher academic status, long term history, bigger numbers of undergraduate students and longer history in integrating soft skills into their curriculum. The sample was chosen randomly from undergraduate population of these universities. To estimate the number, we relied on Krejcie, Robert and Morgan (1970) who suggest 384 samples to be relevant to collect data from any population bigger than 25,000 people. We chose 600 participants, 120 from each university; to be able to provide a reliable comparison among these universities with regard to their students' perception about the integration of soft skills. The questionnaires were distributed among the students in different faculties. All the questionnaires were completed and used in the analysis.

\section{Data Analysis}

The collected data was analyzed using SPSS and Excel software. This section presents the descriptive data including the demographic information collected from the five universities and the results of the statistical procedures, ANOVA and Regression to compare the results obtained from the sample about the undergraduates' perceptions with regard to soft skills, their integration into the courses and the universities' evaluation methods.

\section{A. Descriptive Analysis}

The comparison of the demographic data among the universities didn't show any significant differences, therefore separate information for each university is not included in this report. Tables 5 to 9 represent the demographic information collected from the all 600 participants. As can be seen in the tables presented here, most of the participants were in the age range of 19 to 21 . The number of the female participants was larger, including $68.3 \%$ of the participants. Some of the participants $(39.7 \%)$ reported that they have had work experience, but this experience has been relatively short indicating a period of 3 to 6 months.

The respondents represented a high awareness of the importance of soft skills in their future jobs (86.5\%) and in their perception the most important skill necessary to get a job is communication_ by emphasis on English language, followed by critical thinking, ethics, teamwork and leadership, entrepreneurship and lifelong learning and information management,

Table 5: Age

\begin{tabular}{|l|l|l|l|l|l|}
\hline \multicolumn{2}{|c|}{} & Frequency & Percent & $\begin{array}{l}\text { Valid } \\
\text { Percent }\end{array}$ & $\begin{array}{l}\text { Cumulative } \\
\text { Percent }\end{array}$ \\
\hline \multirow{5}{*}{} & $18-20$ & 2 & .3 & .6 & .6 \\
\cline { 2 - 6 } & $21-23$ & 1 & .2 & .3 & .9 \\
\cline { 2 - 6 } & $24-26$ & 1 & .2 & .3 & 1.2 \\
\cline { 2 - 6 } & 19 & 22 & 3.7 & 6.5 & 8.0 \\
\cline { 2 - 6 } & 20 & 78 & 13.0 & 23.0 & 31.0 \\
\cline { 2 - 6 } & 21 & 100 & 16.7 & 29.5 & 60.5 \\
\cline { 2 - 6 } & 22 & 81 & 13.5 & 23.9 & 84.4 \\
\cline { 2 - 6 } & 23 & 40 & 6.7 & 11.8 & 96.2 \\
\cline { 2 - 6 } & 24 & 5 & .8 & 1.5 & 97.6 \\
\cline { 2 - 6 } & 25 & 3 & .5 & .9 & 98.5 \\
\cline { 2 - 6 } & 26 & 2 & .3 & .6 & 99.1 \\
\cline { 2 - 6 } & 27 & 3 & .5 & .9 & 100.0 \\
\cline { 2 - 6 } & Total & 339 & 56.5 & 100.0 & \\
\hline Missing & System & 261 & 43.5 & & \\
\hline \multicolumn{1}{|c|}{ Total } & 600 & 100.0 & & \\
\hline \multicolumn{2}{|l|}{} & & & & \\
\hline
\end{tabular}

Table 6: Gender

\begin{tabular}{|l|l|l|l|l|l|}
\hline \multicolumn{2}{|c|}{} & Frequency & Percent & $\begin{array}{l}\text { Valid } \\
\text { Percent }\end{array}$ & $\begin{array}{l}\text { Cumulative } \\
\text { Percent }\end{array}$ \\
\hline \multirow{3}{*}{ Valid } & Female & 410 & 68.3 & 68.4 & 68.4 \\
\cline { 2 - 6 } & Male & 189 & 31.5 & 31.6 & 100.0 \\
\cline { 2 - 6 } & Total & 599 & 99.8 & 100.0 & \\
\hline Missing & System & 1 & .2 & & \\
\hline Total & 600 & 100.0 & & \\
\hline
\end{tabular}


Table 7: Race

\begin{tabular}{|l|l|l|l|l|l|}
\hline \multicolumn{2}{|c|}{} & Frequency & Percent & $\begin{array}{l}\text { Valid } \\
\text { Percent }\end{array}$ & $\begin{array}{l}\text { Cumulative } \\
\text { Percent }\end{array}$ \\
\hline \multirow{4}{*}{ Valid } & Malay & 398 & 66.3 & 67.5 & 67.5 \\
\cline { 2 - 6 } & Chinese & 104 & 17.3 & 17.6 & 85.1 \\
\cline { 2 - 6 } & Indian & 14 & 2.3 & 2.4 & 87.5 \\
\cline { 2 - 6 } & Other & 74 & 12.3 & 12.5 & 100.0 \\
\cline { 2 - 6 } & Total & 590 & 98.3 & 100.0 & \\
\hline Missing & System & 10 & 1.7 & & \\
\hline Total & 600 & 100.0 & & \\
\hline
\end{tabular}

Table 8: Work Experience

\begin{tabular}{|c|c|c|c|c|c|}
\hline \multicolumn{2}{|c|}{} & Frequency & Percent & $\begin{array}{c}\text { Valid } \\
\text { Percent }\end{array}$ & $\begin{array}{c}\text { Cumulative } \\
\text { Percent }\end{array}$ \\
\hline \multirow{4}{*}{ Valid } & 0 months & 358 & 59.7 & 60.1 & 60.1 \\
\cline { 2 - 6 } & $\begin{array}{c}3 \text { to } 6 \\
\text { months }\end{array}$ & 237 & 39.5 & 39.8 & 99.8 \\
\cline { 2 - 6 } & $\begin{array}{c}7 \text { to } 12 \\
\text { months }\end{array}$ & 1 & .2 & .2 & 100.0 \\
\cline { 2 - 6 } & Total & 596 & 99.3 & 100.0 & \\
\hline Missing & System & 4 & .7 & & \\
\hline \multicolumn{2}{|c|}{ Total } & 600 & 100.0 & & \\
\hline
\end{tabular}

Table 9: Importance of Acquiring Soft Skills

\begin{tabular}{|l|l|l|l|l|l|}
\hline \multicolumn{2}{|c|}{} & Frequency & Percent & $\begin{array}{l}\text { Valid } \\
\text { Percent }\end{array}$ & $\begin{array}{l}\text { Cumulative } \\
\text { Percent }\end{array}$ \\
\hline \multirow{5}{*}{} & $\begin{array}{l}\text { Strongly } \\
\text { Agree }\end{array}$ & 277 & 46.2 & 47.4 & 47.4 \\
\cline { 2 - 6 } & Agree & 228 & 38.0 & 39.0 & 86.5 \\
\cline { 2 - 6 } Valid & Neutral & 66 & 11.0 & 11.3 & 97.8 \\
\cline { 2 - 6 } & Disagree & 7 & 1.2 & 1.2 & 99.0 \\
\cline { 2 - 6 } & $\begin{array}{l}\text { Strongly } \\
\text { Disagree }\end{array}$ & 5 & .8 & .9 & 99.8 \\
\cline { 2 - 7 } & 11 & 1 & .2 & .2 & 100.0 \\
\cline { 2 - 7 } & Total & 584 & 97.3 & 100.0 & \\
\hline Missing & System & 16 & 2.7 & & \\
\hline Total & & 600 & 100.0 & & \\
\hline
\end{tabular}

\section{B. Statistical Analysis}

Statistical procedures were used to analyze the data collected with regard to students' perception on integration of soft skills in university courses. Also, the achievements of the universities under investigation were compared.

\section{ANOVA}

A single factor ANOVA analysis was conducted to compare the perceptions of students with regard to university performance in integrating the soft skills in the curriculum in different universities. As can be seen in table 10, although there are some variations in soft skill integration in these universities, no significant difference can be observed in their students' perceptions with this regard.
Table 10: Summary of Data and ANOVA for University Performance

\begin{tabular}{|c|c|c|c|c|c|c|}
\hline \multicolumn{2}{|l|}{ Groups } & Count & Sum & \multicolumn{2}{|l|}{ Average } & Variance \\
\hline \multicolumn{2}{|l|}{ Column 1} & 119 & 248.1 & \multicolumn{2}{|l|}{2.084874} & 0.288752 \\
\hline \multicolumn{2}{|l|}{ Column 2} & 121 & 233.6 & \multicolumn{2}{|c|}{1.930579} & 0.259807 \\
\hline \multicolumn{2}{|l|}{ Column 3} & 120 & 253.1 & \multicolumn{2}{|l|}{2.109167} & 0.488235 \\
\hline \multicolumn{2}{|l|}{ Column 4} & 129 & 255.55 & \multicolumn{2}{|c|}{1.981008} & 0.348406 \\
\hline \multicolumn{2}{|l|}{ Column 5} & 116 & 230.6 & \multicolumn{2}{|l|}{1.987931} & 0.347331 \\
\hline \multicolumn{7}{|c|}{ ANOVA University Performance } \\
\hline $\begin{array}{l}\text { Source of } \\
\text { Variation }\end{array}$ & Ss & Df & MS & $\mathbf{F}$ & P-value & $F$ crit \\
\hline $\begin{array}{l}\text { Between } \\
\text { Groups }\end{array}$ & 2.735692 & 4 & 0.683923 & 1.973912 & 0.096952 & 2.386784 \\
\hline $\begin{array}{l}\text { Within } \\
\text { Groups }\end{array}$ & 207.8886 & 600 & 0.346481 & & & \\
\hline Total & 210.6243 & 604 & & & & \\
\hline
\end{tabular}

A single Factor ANOVA was conducted to see if there was a significant difference between the students in the five research universities with regard to the importance value they believe for each soft skill in their employability status. As shown in Table 11, there is no significant difference between perceptions of students studying in different universities on rating the soft skills.

Table 11: Summary and ANOVA or for Students' Importance Value

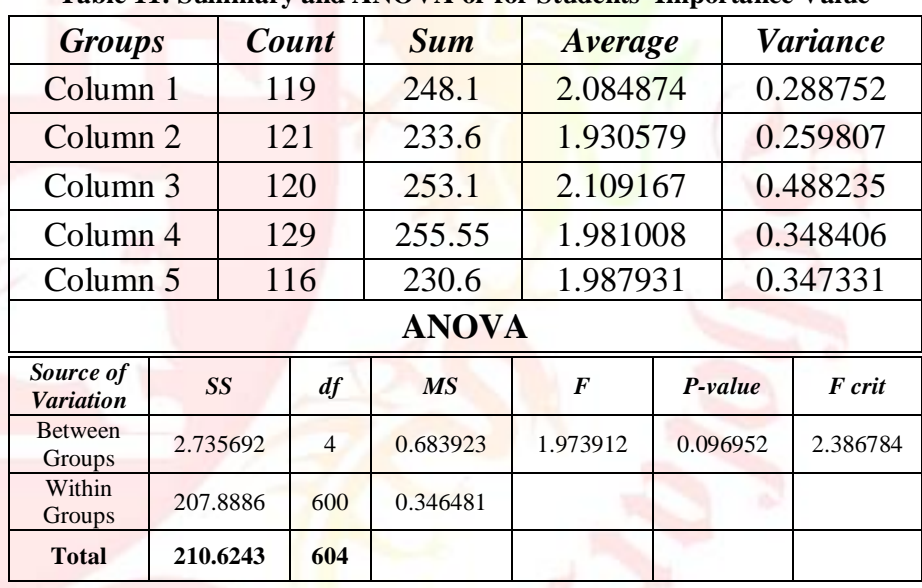

\section{Regression}

Linear Regression was used to specify the universities' scale of importance of soft skills and compare it with that of the students. The results show that the universities give more importance to entrepreneurship, followed by critical thinking, communication, teamwork, ethics and lifelong learning. 
Yinternational Research Journal

p-ISSN 2202-2821 e-ISSN 1839-6518 (Australian ISSN Agency)

Table 12: Regression Descriptive Statistics

\begin{tabular}{|c|c|c|c|}
\hline & Mean & Std. Deviation & $N$ \\
\hline SFintegration & 2.0183408 & .07522632 & 5 \\
\hline communicationS & 2.1731553 & .19435584 & 5 \\
\hline Critical & 2.2247968 & .06678985 & 5 \\
\hline teamwork & 2.0087960 & .04393043 & 5 \\
\hline Lifelong & 1.8503144 & .10135949 & 5 \\
\hline Entrep & 2.5051969 & .14533596 & 5 \\
\hline Ethics & 1.9173027 & .11462016 & 5 \\
\hline
\end{tabular}

Table 13: Regression Residuals Statistics

\begin{tabular}{|c|c|c|c|c|c|}
\hline & Minimum & Maximum & Mean & $\begin{array}{c}\text { Std. } \\
\text { Deviation }\end{array}$ & N \\
\hline Predicted Value & 1.9305785 & 2.1070027 & 2.0183408 & .07522632 & 5 \\
\hline Residual & $0 \mathrm{E}-8$ & $0 \mathrm{E}-8$ & $0 \mathrm{E}-8$ & $0 \mathrm{E}-8$ & 5 \\
\hline $\begin{array}{c}\text { Std. Predicted } \\
\text { Value }\end{array}$ & -1.167 & 1.179 & .000 & 1.000 & 5 \\
\hline Std. Residual &. &. &. &. & 0 \\
\hline
\end{tabular}

Tables 12 and 13 show the summary results for the regression analysis to show how participants have evaluated and rated the importance of soft skills for potential employability. They gave more emphasis on communication, followed by critical thinking, Lifelong learning, Teamwork, Ethics and Entrepreneurship.

\section{V.Discussion}

Acquiring soft skills has been recognized as an important aspect of university curriculum in Malaysian research universities. Lots of effort is taken to integrate these skills into the curriculum. One of the important stakeholders of this process is the large group of undergraduates who will require these skills in the future and expect their courses equip them with these skills. Therefore, their perception about soft skills and universities' success in integrating them in the curriculum can be a valuable factor to assess this process. Our findings show that the undergraduates in these universities have a high level of awareness about the importance of soft skills in their education and future career. They are aware of the efforts done by their lecturers to integrate these skills in their classes.

The interesting outcome is that based on the literature, media reports and our results, the student' perception about soft skills and how they scale them with regard to importance is closer to the perception of the employees rather than the universities. With this regard our participants rated the soft skills as: communication, followed by critical thinking, Lifelong learning, Teamwork, Ethics and Entrepreneurship
Vol. 08 No. 012018

82800801201802

management while universities emphasize on entrepreneurship and critical thinking by providing separate courses highlighting these two skills.

Soft skills are integrated into university curriculum but more work on teaching techniques, methods, quality must be done, and students should be presented with more detailed information about how these skills are evaluated.

As can be seen in the diagram below, these universities have started the process of integrating soft skills into their courses but there is a lot of work to be done to provide professional and practical knowledge to undergraduates. As can be seen in figure 1 below, there is a small difference in the performance of the universities with regard to each skill. Perhaps collaboration between universities would be a good strategy to enhance the integration of soft skills in curriculum. Figures 1 and 2 show a comparison of the means for positive perceptions in the participants from different universities.

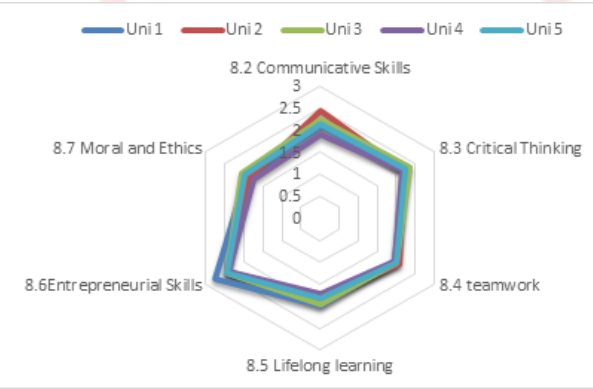

Figure 1: Comparison of five Universities based on Students' Experience in Soft Skills Integration

As can be seen in the radar diagram in figures 1 the difference between universities performance if not significant. All research universities have started integrating soft skills into their curriculum and have been successful to some extent but still there is much to be done to make this integration a beneficial process both for potential employees (undergraduates) and employers. Figure 2 illustrates the same information in bar chart form.

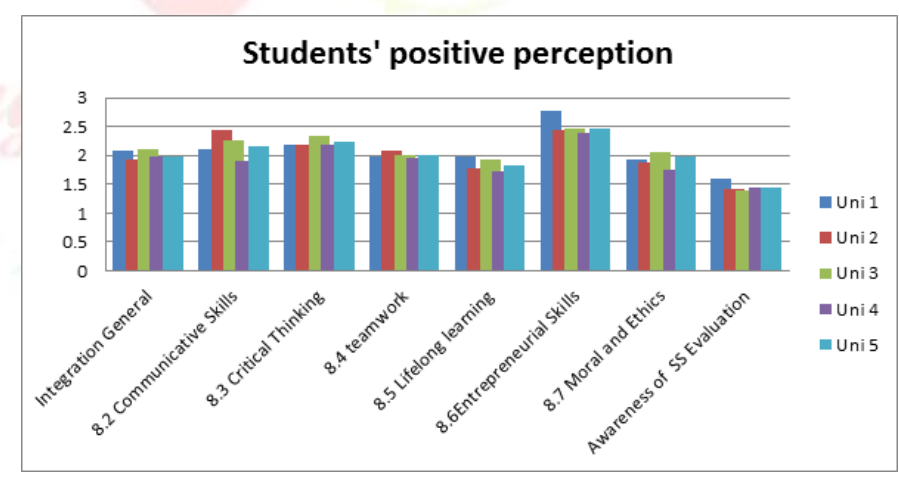

Figure 2: Students’ Positive Perception 


\section{Conclusion}

The necessity of acquiring soft skills for undergraduates is inevitable. To fulfil these needs universities have attempted to integrate these skills into their curriculum. This study was an attempt to assess this integration, its weak and strong points and how it is evaluated in the university system from the students' perception. The results emphasize on the need to develop strategies to enhance the soft skills learning and practicing in the universities. This important aim cannot be achieved without collaboration among universities. On the other hand, universities should consider the employers' and the students' needs and requirements in order to provide practical knowledge and benefit for all stockholders, including academics, employers and potential employees.

This research was conducted to investigate the issue of soft skills integration into the university courses from the perspective of the Malaysian undergraduates in public universities. The results indicate that the students are aware of the importance of soft skills. They evaluate the skills provided by the university as not very effective but admit there some work has been conducted.

Undergraduates believe that soft skills are integrated into the curriculum and they are aware of some of the methods and techniques, which are used to implement this integration, but they lack sufficient knowledge about how and when these skills are evaluated.

To sum up the study we would like highlight the need to train undergraduates so that they acquire soft skills compatible to those, which are demanded in the workplace. The Malaysian public universities have attempted to integrate these skills into their curriculum. This study was an attempt to assess this integration, its weak and strong points and how it is evaluated in the university system from the students' perception. The results emphasise the need to get undergraduates aware and involved both in the learning and evaluation of these skills. This important aim cannot be achieved without the collaboration of the students.

\section{References}

[1]. Act of Workers with 'Soft Skills' Demands a Shift in Teaching (2017). Retrieved from: http://theconversation.com/lack-of-workers-withsoft-skills-demands-a-shift-in-teaching-73433

[2]. Allen, M., \& Yen, W. (2002). Introduction to measurement theory. Long Grove, IL: Waveland Press. (Original work published 1979).

[3]. Bakar, A.R. \& Hanafi, I. (2007). Assessing Employability Skills of Technical-Vocational
Students in Malaysia. Social Sciences, 3(4), $202-$ 207.

[4]. Bland, J.M., Altman, D.G. (1997). Statistics notes: Cronbach's alpha. BMJ.314(7080): 572.doi: 10.1136/bmj.314.7080.572.

[5]. Cronbach, L. J., \& Shavelson, R. J. (2004). Мy current thoughts on coefficient alpha and successor procedures. Educational and Psychological Measurement, 37, 827-838.

[6]. Dunne, E., \& Rawlins, M. (2000). Bridging the gap between industry and higher education: Training academics to promote student teamwork. Innovations in Education and Training International, 37(4), 361-371

[7]. Hairuzila Idrus, Hazadiah Mohd Dahan, Normah Abdullah. (2014). Integrating soft skills in the teaching of hard sciences at a private university: a preliminary study.

[8]. Pertanika Journal of Social Sciences \& Humanities. Volume 22, Special Issue, 17-32.

[9]. Hazmilah, Hasan (2008) Exploring Engineering Employability Competencies Through Interpersonal and Enterprise Skills. $\mathrm{PhD}$ thesis, Coventry University.

[10]. Idrus, Hairuzila (2013) Integration of soft skills in the teaching of technical courses: An exploratory study of a private university / Hairuzila Idrus. PhD thesis, Universiti Teknologi MARA.

[11]. Khairol Mohd Salleh, Nur Lisa Sulaiman, Khairul Nazry Talib. (2010). Globalisation's Impact on Soft Skills Demand in the Malaysian Workforce and Organisations: What Makes graduates employable? Proceedings of the 1st UPI International Conference on Technical and Vocational Education and Training Bandung, Indonesia, 10-11 November 2010

[12]. Krejcie, R.V. \& Morgan, D.W. (1970). Determining sample size for research activities. Educational and Psychological Measurement, 30, 607-610.

[13]. Kvale, S. \& Brinkmann, S. (2009). InterViews: learning the craft of qualitative research interviewing. (2nd edition). Thousand Oaks, CA: Sage

[14]. Lee Fui Tong (2003). "Identifying essential learning skills in students' engineering education, Monash University Malaysia. Retrieved from: http://surveys. canterbury.ac.nz/herdsa03/pdfsref / Y1111.Pdf

[15]. McLarty, R. (2000) Evaluating Graduate Skills in SMEs: the value chain impact, Journal of Management Development, 19, pp. 615-628. 
[16]. Ministry of Higher Education Malaysia. (2006). Development of soft skills for Institutions of Higher Learning. Universiti Putra Malaysia.

[17]. Moss, P. \& Tilly, C. (1996). Growing demand for "soft" skills in four industries: Evidence from indepth employer interviews. (Working Paper No. 93). New York: Russell Sage Foundation.

[18]. Rahmah Ismail, Ishak Yussof and Lai Wei Sieng, 2011. Employers' Perceptions on Graduates in Malaysian Services Sector. International Business Management, 5: 184-193.

[19]. Ramakrishnan, K. \& Norizan Mohd Yasin. (2012). Employment issues among Malaysian information and communication technology (ICT) graduates: A case study. African Journal of Business Management 6(16), pp. 5615-5621.

[20]. Riam Chau Mai (2012). Developing Soft Skills in Malaysian Polytechnic: Students ${ }^{e e}$ perspectives of employers and students. Asian Journal of Management Sciences and Education, 1(2): 44- 51.

[21]. Roberto M. Fernandez, , Jason Greenberg, (2013), Race, Network Hiring, and Statistical Discrimination, in Steve Mcdonald (ed.) Networks, Work and Inequality Research in the Sociology of Work, Volume 24 Emerald Group Publishing Limited, pp.81 - 102

[22]. Roselina Shakir (2009). Soft skills at the Malaysian institutes of higher learning. Asia Pacific Education Review, 10(3), 309-315.

[23]. Shah, N. Z. (2008). Are graduates to be blamed? Unemployment of computer science graduates in Malaysia. Retrieved from, http:// aabss.org/journal2008/AABS2008Article6NORSHI MAZSHAH.pdf. 30

[24]. Shirley Ken Tzu Ting, Cheah Yeh Ying (2012). Is There a Gap between Practitioners' and Academicians' Perceptions on Business Graduates' Competencies in Malaysia? Journal of Education and Vocational Research Vol. 3, No. 5, pp. 167-172.

[25]. Sidhu, J. S. (2011, Feb 12). The scramble for skills. The Star Online. Retrieved from: http://biz.thestar.com.my/news/story. asp?file=/2011/2/12/business/8051679 31 .

[26]. Singh, G. K. G., \& Singh, S. K. G. (2008). Malaysian graduates employability skills. UNITAR E-Journal, 4(1), 15-45. 32.

[27]. Thanh Nguyen (2016), Employers lament lack of soft skills in graduates Issue No:397. Retrieved from:

http://www.universityworldnews.com/article.php?st ory $=20160119123408402$
[28]. Verney, T. P., Holoviak, S. J., \& Winter, A. S. (2009). Enhancing the reliability of internship evaluations. Journal of Applied Business and Economics, 9(1), 22-33. 33.

[29]. White, Martha C. (2013), The Real Reason New College Grads Can't Get Hired. Retrieved from: http://business.time.com/2013/11/10/the-realreason-new-college-grads-cant-get-hired/

[30]. Woo, K. Y. (2006). Malaysian private higher education: A need to study the different interpretations of quality. Retrieved from: http://www.ucsi.edu.my/research/jasa/1/papers/10Apg17.pdf

[31]. Yasmin Mohd Adnan et.al (2012). Importance of Soft Skills for Graduates in the Real Estate Programs. Malaysia.Journal of Surveying, Construction and Property.3(2).

[32]. Zaharim A., Md Yusoff Y., Omar M.Z., Mohamed A., Muhamad N., Mustapha R. (2009). Engineering Employability Skills Required By Employers In Asia. 6th WSEAS International Conference on Engineering Education (EE '09), Rodos, Greece, (pp195-201). 